\title{
The Genetic Code: A Classic Example of Substitution Phenomenon in Science
}

\section{Bozegha WB}

Development Research Project, Yenagoa, Bayelsa State, Nigeria

*Corresponding author: Bozegha WB, Development Research Project, Yenagoa, Bayelsa State, Nigeria, Tel: +2348068029860; E-mail: wbbozegha@yahoo.co.in

Received date: February 08, 2018; Accepted date: February 16, 2018; Published date: February 26, 2018

Copyright: (c) 2018 Bozegha WB. This is an open-access article distributed under the terms of the Creative Commons Attribution License, which permits unrestricted use, distribution, and reproduction in any medium, provided the original author and source are credited.

\section{Introduction}

Substitution phenomena abound in human experience in Science and Scripture making the two sides of the coin of Creation. Some natural, some man-made, but all are aimed at enhanced profitab it or improvement of performance or $\mathrm{s} \mathrm{mpl}$ ficat on of process of minification of labour, etc. Examples of man-made substitution.

phenomena include Panama Canal and Suez Canal in voyaging concerns and many others in sporting encounters. e natural include the navel as substitute to the mouth in pre-natal feeding of humans (fetuses) in mother's womb, and before we come to the genetic code, our classic example in protein synthesis, there is yet to be mentioned the supreme example of substitution phenomenon in Scripture involving the death of Jesus Christ on the Cross of Calvary in place of sinners upon divine intervention for the salvation of man, hitherto doomed to die because of death inherited from Adam and sins committed [1,2].

The search for genetic code was prompted by Molecular Biologists' observation in 1953 that the sequence of the RNA four bases A,U,G,C (Adenine, Uracil, Guanine, Cytosine) in the nucleus of a cell nfluenced the sequence of the 20 amino acids of protein in the surrounding cytoplasm of the cell as they desired to know what governed the correlation between 4 bases and 20 amino acids in the cell. e consequently dent fied the interaction between the two entities incidental to protein synthesis. Protein synthesis of course with a goal to protein type proliferation and d vers ficat on is geared to meeting the stupendous need of proteins for sustenance of plants and animals throughout nature since creation (Figure 1). Ordinarily, the set of 20 amino acids constituting a protein type could be used as input set in the combinatorial input/output multiplicative replication system to achieve astounding proliferation and $\mathrm{d}$ vers ficat on of proteins. It would be permutation of 20 from 20 i.e., $20 \mathrm{P} 20=20$ ! And by tower multiplication we have $20 \times 19 \times 18 \times 17 \ldots 4 \times 3 \times 2 \times 2 \times$ $1=2,432,902,008,176,640,000$ protein types $[3,4]$.

\begin{tabular}{|c|c|c|c|c|c|c|}
\hline 2 & 432 & 902 & 008 & 176 & 640 & 000 \\
\hline \multirow[b]{7}{*}{2} & \multirow[b]{6}{*}{432} & \multirow[b]{5}{*}{902} & \multirow[b]{4}{*}{008} & \multirow[b]{3}{*}{176} & \multirow[b]{2}{*}{640} & 000 \\
\hline & & & & & & Thousand \\
\hline & & & & & \multicolumn{2}{|c|}{ Million } \\
\hline & & & & \multicolumn{3}{|c|}{ Billion } \\
\hline & & & \multicolumn{4}{|c|}{ Trillion } \\
\hline & & \multicolumn{5}{|c|}{ Quadrillion } \\
\hline & \multicolumn{6}{|c|}{ Quintillion } \\
\hline
\end{tabular}

Figure 1: Metric Count Gravimetiser.

s 19-digit count denominated in metric system by the metric count gravimetiser Figure 1 is 2 quintillion, 432 quadrillion, 902 trillion, 8 billion, 176 million, 640 thousand. It is astounding in proliferation and d vers ficat on of proteins but obviously unwieldy for human intellectual capacity, so the all-wise Creator opted for the 4 RNA bases A,U,G,C (Adenine, Uracil, Guanine, Cytosine) as substitute input set of 4 , instead of the set of 20 amino acids in the input/output multiplicative replication system. s becomes permutation of 4 from 4 i.e., $4 \mathrm{P} 4=4$ ! $=4 \times 3 \times 2 \times 1=24$ quadruplets representing the true genetic code as derived in Appendix 1 being engaged in protein synthesis throughout nature since creation [5]

This genetic code of 24 quadruplet codons affords collinearity with the 20 amino acids of protein on one to one correspondence with 4 spare codons for four place and time based start/stop control signals in protein synthesis.

\section{Conclusion}

Thus, the 24 quadruplet genetic code is the primary workforce of strength 24 engaged in protein synthesis. e protein type proliferation and $\mathrm{d}$ vers ficat on is drastically cut down from the 19-digit unwieldy fiure to a mere 2-digit number, 24 through divine grace and initiative of substitution phenomenon for human intellectual operational capacity. By this substitution phenomenon moderate, nevertheless adequate, protein type proliferation and $\mathrm{d}$ vers ficat on is now realized, to the end that one set of RNA four bases A, U, G, C as input set gives an output sequence of genetic code of 24 quadruplets for the formation of one protein type of 20 amino acids in a sequence corresponding to that of the genetic code codons. e cycle of engagement of the 24 quadruplet codons as input set continued and with their potency the proliferation and d vers ficat on of protein types is seen to be e ect vel maintained throughout nature since creation. 
Citation: Bozegha WB (2017) The Genetic Code: A Classic Example of Substitution Phenomenon in Science. J Bioprocess Biotech 8: 316. doi: 10.4172/2155-9821.1000316

Page 2 of 2

\section{Recommendation}

Let this 24 quadruplet genetic code be widely publicized to attract experimental experts in genetics to spell it in order to render it fit for coding application in protein synthesis studies.

\section{References}

1. Wang K, Schmied WH, Chin JW (2012) Reprogramming the Genetic Code: From Triplet Quadruplet Codes. Angewante Minireviews Angwe. Chem Int Ed 51: 2288-2297.
2. Anderson JC, Wu N, Santoro SW (2004) An Expanded Genetic Code With A Functional Quadruplet Codon. Proc Natl Acad Sci 20: 7566-7571.

3. Dieter S, Rajbhandary UL (2006) The genetic code-Thawing the "Frozen accident". J Biosci 34: 459-463.

4. Agris PF (2004) Decoding the genome: A modified view. Nucleic Acids Res 32: 223-238.

5. Nirenberg M, Leder P (1964) RNA codewords and protein synthesis: the effect of trinucleotides upon the binding of sRNA rebosomes. Science 145: 1399-1407. 